\title{
Effect of Free Nitrous Acid on Nitrous Oxide Production and Denitrifying Phosphorus Removal by Polyphosphorus-Accumulating Organisms in Wastewater Treatment
}

\author{
Zhijia Miao ${ }^{10},{ }^{1,2,3,4}$ Duo Li, ${ }^{1,2,3,4}$ Shan Guo, ${ }^{1,2,3,4}$ Zhirui Zhao, ${ }^{1,2,3,4}$ Xiaofeng Fang, ${ }^{1,2,3,4}$ \\ Xueyou Wen, ${ }^{1,2,3,4}$ Jingmin Wan, ${ }^{1,2,3,4}$ and Aiguo $\mathrm{Li}^{1,2,3,4}$ \\ ${ }^{1}$ School of Water Resources and Environment, Hebei GEO University, Shijiazhuang 050031, China \\ ${ }^{2}$ Hebei Province Key Laboratory of Sustained Utilization and Development of Water Resources, Shijiazhuang 050031, China \\ ${ }^{3}$ Hebei Province Collaborative Innovation Center for Sustainable Utilization of Water Resources and Optimization of \\ Industrial Structure, Shijiazhuang 050031, China \\ ${ }^{4}$ Research Center of Natural Resources Assets, Hebei GEO University, Shijiazhuang 050031, China
}

Correspondence should be addressed to Zhijia Miao; zhijia_miao@163.com

Received 28 December 2017; Accepted 18 March 2018; Published 26 April 2018

Academic Editor: Joseph Usack

Copyright (c) 2018 Zhijia Miao et al. This is an open access article distributed under the Creative Commons Attribution License, which permits unrestricted use, distribution, and reproduction in any medium, provided the original work is properly cited.

The inhibition of free nitrous acid (FNA) on denitrifying phosphorus removal has been widely reported for enhanced biological phosphorus removal; however, few studies focus on the nitrous oxide $\left(\mathrm{N}_{2} \mathrm{O}\right)$ production involved in this process. In this study, the effects of FNA on $\mathrm{N}_{2} \mathrm{O}$ production and anoxic phosphorus metabolism were investigated using phosphorusaccumulating organisms (PAOs) culture highly enriched $(91 \pm 4 \%)$ in Candidatus Accumulibacter phosphatis. Results show that the FNA concentration notably inhibited anoxic phosphorus metabolism and phosphorus uptake. Poly- $\beta$-hydroxyalkanoate (PHA) degradation was completely inhibited when the FNA concentration was approximately $0.0923 \mathrm{mgHNO}_{2}-\mathrm{N} / \mathrm{L}$. Higher initial FNA concentrations ( 0.00035 to $0.0103 \mathrm{mgHNO}_{2}-\mathrm{N} / \mathrm{L}$ ) led to more PHA consumption/TN (0.444 to $0.916 \mathrm{mmol}-\mathrm{C} /(\mathrm{mmol}-\mathrm{N} \cdot \mathrm{gVSS})$ ). Moreover, it was found that FNA, rather than nitrite and $\mathrm{pH}$, was likely the true inhibitor of $\mathrm{N}_{2} \mathrm{O}$ production. The highest proportion of $\mathrm{N}_{2} \mathrm{O}$ to TN was $78.42 \%$ at $0.0031 \mathrm{mgHNO}_{2}-\mathrm{N} / \mathrm{L}$ (equivalent to $42.44 \mathrm{mgNO}_{2}-\mathrm{N} / \mathrm{L}$ at pH 7.5), due to the simultaneous effects of FNA on the subsequent conversion of $\mathrm{NO}_{2}$ into $\mathrm{N}_{2} \mathrm{O}$ and then into $\mathrm{N}_{2}$. The traditional nitrite knee point can only indicate the exhaustion of nitrite, instead of the complete removal of TN.

\section{Introduction}

Enhanced biological phosphorus removal (EBPR), operated with sequential anaerobic and aerobic periods, is considered as an efficient method for phosphorus removal. A group of bacteria known as polyphosphate-accumulating organisms (PAOs) are able to take up volatile fatty acids (VFAs) and store them as poly- $\beta$-hydroxyalkanoates (PHAs), which has been attributed to phosphorus release during the anaerobic phase. In the subsequent aerobic phase, PAOs use the stored PHA as an energy source for biomass growth and take up orthophosphate into polyphosphate (poly-p). Finally, phosphorus is removed from the system through the wastage of excess sludge. Phosphorus uptake also occurs under anoxic conditions. Previous studies have identified a subset of PAOs, known as denitrifying phosphorus-accumulating organisms (DPAOs), which can also denitrify and are able to oxidize intracellular PHA for energy and nitrite or nitrate as electronic acceptors, instead of oxygen, to remove phosphorus [13]. Compared to conventional biological nitrogen and phosphorus removal, DPAOs can take up a carbon source during the anaerobic phase, which could be used for both denitrification and phosphorus removal. Thus, the DPAO pathway is advantageous for the treatment of wastewater containing a relatively low level of organic carbon, while requiring less oxygen and resulting in lower sludge production. 
$\mathrm{N}_{2} \mathrm{O}$, which is a significant greenhouse gas, has 300 times greater warming potential than $\mathrm{CO}_{2}$ (IPCC, 2001). Most research on the pathway of nitrification, denitrification, and phosphorus removal has been conducted that $\mathrm{N}_{2} \mathrm{O}$ was produced in wastewater treatment systems. The production of $\mathrm{N}_{2} \mathrm{O}$ may be affected by many parameters, such as low dissolved oxygen concentrations, accumulation of nitrite, types of organic carbon sources, $\mathrm{pH}$, and temperature $[4,5]$. It has been frequently reported that the accumulation of nitrite leads to increased $\mathrm{N}_{2} \mathrm{O}$ emission, rather than $\mathrm{N}_{2}$, as the major end-product in the denitrifying phosphorus removal processes [6,7]. Zhou et al. showed that free nitrous acid (FNA), rather than nitrite or $\mathrm{pH}$, is likely the true inhibitor of $\mathrm{N}_{2} \mathrm{O}$ reduction by DPAOs [8]. Wang et al. also observed the inhibitory effect of FNA on the $\mathrm{N}_{2} \mathrm{O}$ reduction activity in a denitrifying phosphorus removal system [9]. These results indicate that FNA is associated with denitrifying phosphorus removal and $\mathrm{N}_{2} \mathrm{O}$ production.

The level of the FNA can also affect the anoxic or aerobic phosphorus metabolism of PAOs. Zhou et al. reported that the concentration of FNA influenced the efficiency of anoxic phosphorus uptake. Specifically, the PAO uptake process was inhibited at lower FNA levels $\left(<0.002 \mathrm{mg} \mathrm{HNO}_{2}-\mathrm{N} / \mathrm{L}\right)$ and ceased at an FNA concentration of $0.02 \mathrm{mg} \mathrm{HNO}_{2}-\mathrm{N} / \mathrm{L}$ [10]. It was found that FNA inhibited all key aerobic metabolic processes performed by a culture highly enriched $(90 \pm 5 \%)$ in Candidatus Accumulibacter phosphatis [11]. In contrast, some studies revealed that PAOs could acclimate to nitrite as the sole electron acceptor without experiencing inhibition $[12,13]$.

Most studies in this field have taken great efforts to understand the key roles of FNA in the metabolic processes of PAOs. Previous research has shown that $\mathrm{N}_{2} \mathrm{O}$ production accompanies denitrifying phosphorus removal; however, little attention has been given to the effect of nitrite/FNA on $\mathrm{N}_{2} \mathrm{O}$ production by highly enriched PAOs. The PAOs, named Candidatus Accumulibacter phosphatis, are dominant in both lab-scale EBPR reactors and full-scale wastewater treatment plants (WWTPs) [14-17]. If PAOs contribute to $\mathrm{N}_{2} \mathrm{O}$ emission, we cannot ignore their role in WWTP operations. Therefore, the impact of nitrite/FNA on $\mathrm{N}_{2} \mathrm{O}$ production in anoxic denitrifying phosphorus removal by PAOs should be further investigated.

In this study, a series of batch tests were carried out using a highly enriched culture of Candidatus Accumulibacter phosphatis under different $\mathrm{pH}$ values and nitrite concentrations. The objective was to determine the effects of FNA on PHA oxidation, nitrite reduction, phosphorus uptake, and $\mathrm{N}_{2} \mathrm{O}$ accumulation during denitrifying phosphorus removal and to determine whether these effects are associated with $\mathrm{N}_{2} \mathrm{O}$ metabolism.

\section{Methods}

2.1. Reactor and Operation. A laboratory-scale sequence batch reactor (SBR) with a working volume of $8 \mathrm{~L}$ was operated for 241 days under anaerobic-aerobic conditions. The SBR was fed with acetate or propionate switching at a frequency of one to two sludge ages. The cycle time was
$6 \mathrm{~h}$ and consisted of a $150 \mathrm{~min}$ anaerobic period, a $180 \mathrm{~min}$ aerobic period, $25 \mathrm{~min}$ settle/decant period, and a $5 \mathrm{~min}$ idle period. In each cycle, $2 \mathrm{~L}$ of synthetic wastewater was fed to the reactor in the first $6 \mathrm{~min}$ of the anaerobic period, resulting in a hydraulic retention time (HRT) of $24 \mathrm{~h}$. At the end of the cycle, $200 \mathrm{ml}$ sludge was removed to achieve a solids retention time (SRT) of approximately 10 days and a mixed liquor suspended solid (MLSS) level of $2.5-3.5 \mathrm{~g} / \mathrm{L}$. The dissolved oxygen (DO) concentration was maintained at $2.0 \pm$ $0.2 \mathrm{mg} / \mathrm{L}$ in aerobic period, using an online on/off controller. The $\mathrm{pH}$ was controlled during both the anaerobic and aerobic phases at the range of 7.2-8.0 through dosed 0.5 MHCL and $0.5 \mathrm{MNaOH}$. The temperature was maintained at $20^{\circ} \mathrm{C}$.

2.2. Synthetic Wastewater. The $2 \mathrm{~L}$ synthetic wastewater described by Miao et al. was composed of $0.3 \mathrm{~L}$ of solution $\mathrm{A}$ and $1.7 \mathrm{~L}$ of solution $\mathrm{B}$ [18]. The mixed feed of solutions $\mathrm{A}$ and $\mathrm{B}$ contained $800 \mathrm{COD} / \mathrm{L}$ and $40 \mathrm{mgP} \cdot \mathrm{L}^{-1}$. Solution A contains (per liter) $3.41 \mathrm{~g}$ acetate or $1.76 \mathrm{ml}$ propionic acid. In addition, solution A also contains (per liter) $1.02 \mathrm{~g} \mathrm{NH}_{4} \mathrm{Cl}$, $0.01 \mathrm{~g}$ peptone, $0.01 \mathrm{~g}$ yeast extraction, $1.20 \mathrm{gMgSO}_{4} \cdot 7 \mathrm{H}_{2} \mathrm{O}$, $0.19 \mathrm{~g} \mathrm{CaCl}_{2} \cdot 2 \mathrm{H}_{2} \mathrm{O}, 7.94$ mgallyl-N thiourea (ATU, a nitrification inhibitor), and $4.00 \mathrm{~mL}$ trace elements liquid. Solution B contained (per liter) $173 \mathrm{mg} \mathrm{K} \mathrm{KPO}_{4} \cdot 3 \mathrm{H}_{2} \mathrm{O}$ and $104 \mathrm{mg}$ $\mathrm{KH}_{2} \mathrm{PO}_{4}$. For the propionic acid feed, $10.47 \mathrm{ml}$ of $5 \mathrm{M} \mathrm{NaOH}$ was used to adjust the $\mathrm{pH}$ to 7.5 .

\subsection{Batch Experiments}

2.3.1. Batch Experiment 1. The tested sludge was taken from a SBR that was fed with acetate during the normal cycle. At the end of the anaerobic stage, the mixed liquor $(6 \mathrm{~L})$ was divided into six parts and put into a $1.25 \mathrm{~L}$ batch reactor. $\mathrm{NaNO}_{2}$ $(0.1971 \mathrm{~g})$ was added to the batch reactors under different $\mathrm{pH}$ conditions, resulting in the initial nitrite concentrations varying between 39.98 and $48.63 \mathrm{mg} \mathrm{NO}$-N/L. FNA concentration, $\mathrm{pH}$, temperature, and anoxic operating time are shown in Table 1 . The concentration of FNA $\left(\mathrm{HNO}_{2}-\mathrm{N}\right)$ was calculated according to the following formula:

$$
\mathrm{FNA}=\frac{S_{\left(\mathrm{NO}_{2}{ }^{-}-\mathrm{N}\right)}}{K_{a} \times 10^{\mathrm{pH}}}, \quad K_{a}=e^{-2300 /(273+T)}
$$

(see [19]). In each set, the $\mathrm{pH}$ was kept approximately constant $( \pm 0.1)$ at a set-point, by manually adding $0.2 \mathrm{M} \mathrm{HCl}$ or $0.2 \mathrm{M}$ $\mathrm{NaOH}$.

2.3.2. Batch Experiment 2. The tested sludge was taken from a SBR at the end of the anaerobic stage. Six sets of batch tests were performed similar to that described above. The details are shown in Table 1.

2.4. Analytical Methods. The liquid samples were immediately filtered through Millipore filter units $(0.45 \mu \mathrm{m}$ pore size) for analysis of COD, VFA, $\mathrm{NO}_{2}-\mathrm{N}, \mathrm{NO}_{3}-\mathrm{N}$, and $\mathrm{PO}_{4}-$ P. During the experiment, $\mathrm{COD}, \mathrm{NO}_{2}-\mathrm{N}$, and $\mathrm{PO}_{4}-\mathrm{P}$ were measured according to standard methods (APHA, 1998).

PHA analysis was performed using the method of Miao et al. to determine poly- $\beta$-hydroxybutyrate (PHB), 


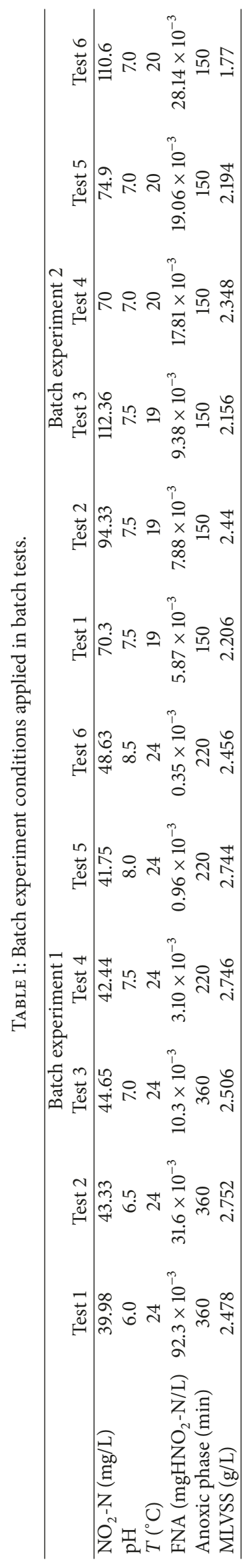


poly- $\beta$-hydroxyvalerate (PHV), and poly- $\beta$-hydroxy-2methylvalerate (PH2MV) [18]. Weighed freeze-dried biomass, $2 \mathrm{ml}$ chloroform, and $2 \mathrm{ml}$ methanol acidified with $3 \% \mathrm{H}_{2} \mathrm{SO}_{4}$ were added to glass tubes, respectively, and then the tubes were heated in $100^{\circ} \mathrm{C}$ for $20 \mathrm{~h}$ after being mixed. One millilitre of Milli- $\mathrm{Q}$ water was put into the tubes and mixed after cooling. After centrifugation, $1400 \mathrm{ml}$ of the bottom organic phases was added to GC vial for analysis. The temperatures of injector and FID detector were maintained at $200^{\circ} \mathrm{C}$ and $250^{\circ} \mathrm{C}$. The temperature program was set as follows: it was held at $80^{\circ} \mathrm{C}$ for $2 \mathrm{~min}$; increased to $140^{\circ} \mathrm{C}$ at the rate of $10^{\circ} \mathrm{C} / \mathrm{min}$, and then maintained for $1 \mathrm{~min}$. Glycogen was measured according to the method described by Lopez-Vazquez. Five millilitres of $0.6 \mathrm{M} \mathrm{HCl}$ was added to weighed freeze-dried biomass in crew-toped glass tubes and then heated at $105^{\circ} \mathrm{C}$ for $6 \mathrm{~h}$ [20]. After cooling and centrifugation, $1 \mathrm{ml}$ of the supernatant was transferred to a high performance liquid chromatography vial for glucose analysis. $\mathrm{N}_{2} \mathrm{O}$ analysed was using the $\mathrm{N}_{2} \mathrm{O}$ sensor by microsensor multimeter.

Fluorescence in situ hybridization (FISH) was performed with cy5-labelled EUBMIX probes (for most bacteria), cy3labelled GAOMIX probes (for competibacter, comprising equal amounts of probes GAO431 and GAO 989), and cy3labelled PAOMIX (for Candidatus Accumulibacter phosphatis or Accumulibacter, comprising equal amounts of probes $\mathrm{PAO} 462, \mathrm{PAO} 651$, and PAO846) [21, 22].

\section{Results and Discussion}

3.1. Reactor Performance and Microbial Community. The SBR was operated for 241 days under anaerobic/aerobic conditions. The reactor was fed with acetate or propionate, which was switched at a frequency of one to two sludge ages. The phosphorus removal performance is shown in Figure 1(a). During the first 45 days, the phosphorus removal efficiency was not stable, with the P concentration higher in the effluent than in the influent for some days. The pump supplying the carbon source malfunctioned from days 83 to 85 , leading to a shortage of carbon sources during the anaerobic metabolic process; thus, the P removal efficiency declined in the effluent. After the 95th day, the $\mathrm{P}$ concentration in the effluent was stably maintained at less than $0.8 \mathrm{mg} / \mathrm{L}$ for the remainder of the operation. The $\mathrm{P}$ concentration at the end of the anaerobic stage averaged $130 \mathrm{mg} / \mathrm{L}$ when fed with acetate, which was higher than when fed with propionate as the carbon source (approximately $80 \mathrm{mg} / \mathrm{L}$ ). The composition of the microbial population was characterised using FISH (Figures $1(\mathrm{~b})$ and 1(c)). FISH results showed that the abundance of Accumulibacter was initially $3 \%$ of the total bacteria on day 1 and then rose to $91 \%( \pm 4 \%)$ on day 241 . The glycogen accumulating organisms (GAOs) were hardly detected on the 241st day. After 241 days of sludge domestication, the fraction of PAOs could utilize nitrite instead of oxygen as electron acceptor was to be found. In addition, high $\mathrm{N}_{2} \mathrm{O}$ accumulation occurred during the denitrifying phosphorus removal process. One possible explanation was that FNA affected this phase. Thus, batch experiments 1 and 2 were designed to investigate the influence of FNA on anoxic phosphorus metabolism by PAOs.

\subsection{Effect of FNA on Denitrifying Phosphorus Removal and $\mathrm{N}_{2} \mathrm{O}$ Production in Batch Experiment 1}

3.2.1. Comparison of Nitrite Reduction in Batch Experiment 1. The variations in nitrite concentrations during the anaerobic denitrifying phosphorus process were monitored throughout batch experiment 1 (Figure 2(a)). Following addition of $40 \mathrm{mgN} / \mathrm{L}$ nitrite, the nitrite concentration decreased rapidly at the ranges of $0.0031,0.00096$, and $0.00035 \mathrm{mgHNO}_{2}-\mathrm{N} / \mathrm{L}$ (corresponding to $\mathrm{pH} 7.5,8.0$, and 8.5 conditions, resp.) (Figure 2(a)), thereby resulting in nitrite reduction rates of $8.15,8.25$, and $11.7 \mathrm{mgNO}_{2}-\mathrm{N} /(\mathrm{h} \cdot \mathrm{gVSS})$, respectively. With the decrease of FNA, the nitrite reduction rate slowed and reached 1.16, 2.14, and $4.82 \mathrm{mgNO}_{2}-\mathrm{N} /(\mathrm{h} \cdot \mathrm{gVSS}$ ), corresponding to $0.0923,0.0316$, and $0.0103 \mathrm{mgHNO}_{2}-\mathrm{N} / \mathrm{L}$. In several studies the denitrifying phosphorus removal process was restrained at lower nitrite concentrations from approximately 5 to $10 \mathrm{mgN} / \mathrm{L}[3,23]$. In this study, nitrite addition of approximately $40 \mathrm{mg} \mathrm{NO}_{2}-\mathrm{N} / \mathrm{L}$ was not inhibitory to the anoxic metabolism of the PAOs at the FNA concentrations of 0.0103 , $0.0031,0.00096$, and $0.00035 \mathrm{mgHNO}_{2}-\mathrm{N} \cdot \mathrm{L}^{-1}$. However, the nitrite reduction rate was inhibited at FNA concentrations of 0.0923 and $0.0316 \mathrm{mgHNO}_{2}-\mathrm{N} / \mathrm{L}$. This result suggests that nitrite is not a main inhibitor of the denitrifying phosphorus removal process when $39.98-48.63 \mathrm{mg} \mathrm{NO} \mathrm{N}_{2}-\mathrm{N} / \mathrm{L}$ was added at the beginning of the experiment. Our findings are consistent with the research conducted by Zhou et al., who reported that FNA, rather than nitrite, was likely the true inhibitor of anoxic phosphorus uptake [10]. In that study, the concentration ranged from 0.002 to $0.02 \mathrm{mg} \mathrm{HNO}_{2}-\mathrm{N} / \mathrm{L}$ and anoxic phosphorus uptake ceased at $0.02 \mathrm{mg} \mathrm{HNO}_{2}$-N/L. In this study, nitrite reduction occurred at an FNA concentration of $0.0923 \mathrm{mgHNO}{ }_{2}-\mathrm{N} \cdot \mathrm{L}^{-1}$. A possible explanation is that the higher proportion of PAOs ( $91 \%( \pm 4 \%)$ of the total bacteria) would be tolerant of higher FNA concentrations.

\subsubsection{Comparison of Phosphorus Uptake in Batch Experi-} ment 1. Figure 2(b) shows the phosphorus concentration profiles measured in batch experiment 1 . Similar to the nitrite reduction rate, phosphorus uptake occurred rapidly at the ranges of $0.0031,0.00096$, and $0.00035 \mathrm{mgHNO}_{2}-\mathrm{N} / \mathrm{L}$, and the average rates were determined as $6.13,8.10$, and $8.63 \mathrm{mgP} /(\mathrm{h} \cdot \mathrm{gVSS})$, respectively. The phosphorus concentration decreased rapidly during the initial stage under these three conditions, with the turning point occurring when the terminal nitrite concentration was less than $0.5 \mathrm{mgN} / \mathrm{L}$. However, the rate decreased sharply after the turning point (2.418, 3.686 , and $3.715 \mathrm{mgP} /(\mathrm{h} \cdot \mathrm{gVSS})$ ), when $\mathrm{N}_{2} \mathrm{O}$ replaced nitrite as the sole electronic acceptor. The concentration of phosphorus slightly decreased when FNA declined to $0.0316 \mathrm{mgHNO}_{2}$ N/L. Moreover, denitrifying phosphorus removal was completely inhibited at $0.0923 \mathrm{mgHNO}_{2}-\mathrm{N} / \mathrm{L}$, suggesting that phosphorus release occurs instead of phosphorus uptake under this condition. This observation confirms that PAO metabolism during the anoxic phosphorus removal process may be inhibited by FNA and that poly-P would be released 


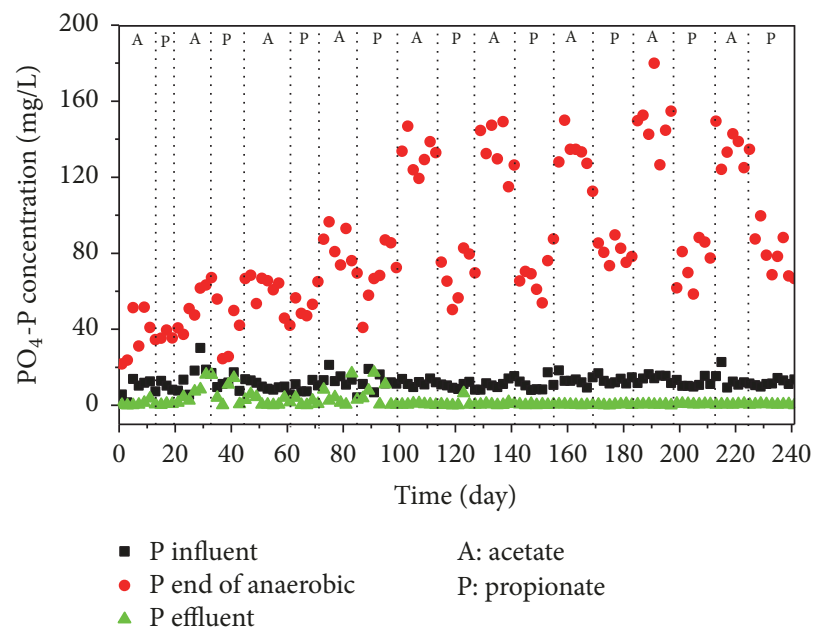

(a)

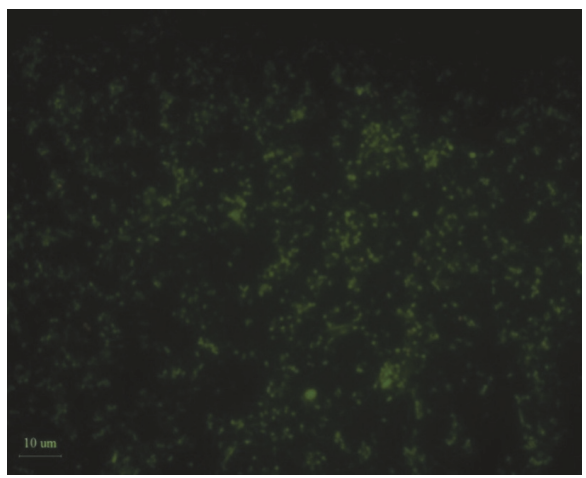

(b)

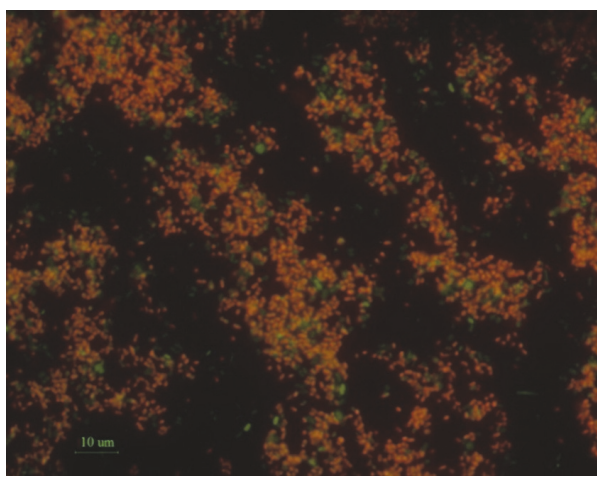

(c)

FIgURE 1: Performance of the reactor and FISH results: (a) Phosphorus removal performance; (b) FISH image of day 1; (c) FISH image of day 241.

from intracellular or dead biomass under these circumstances.

Figure 3 shows that the average $\mathrm{P}$ uptake rate significantly correlated with the FNA concentration, indicating the importance of FNA in the denitrifying phosphorus process. The rates were between -2.08 and $8.63 \mathrm{mgP} /(\mathrm{h} \cdot \mathrm{gVSS})$, which is higher than some previously published research [10]. However, these rates were still lower than using oxygen as the electron acceptor when operated at normal cycle (data not shown). Therefore, it could be deduced that the nitrite is denitrified by PAOs when the concentration of FNA is below inhibitory levels.

3.2.3. Comparison of $\mathrm{N}_{2} \mathrm{O}$ Production in Batch Experiment 1. High concentrations of $\mathrm{N}_{2} \mathrm{O}$ accumulated during the denitrifying phosphorus removal process by PAOs, with the fact that the concentration of $\mathrm{N}_{2} \mathrm{O}$ peaked when nitrite was exhausted (Figure 2(c)). This result suggests that it has different reduction rates between the different steps during the anoxic phosphorus removal process, namely, $\mathrm{NO}_{2}{ }^{-}$to $\mathrm{N}_{2} \mathrm{O}$ and $\mathrm{N}_{2} \mathrm{O}$ to $\mathrm{N}_{2}$, thereby leading to $\mathrm{N}_{2} \mathrm{O}$ accumulation. Some studies have shown that nitrite reductase and $\mathrm{N}_{2} \mathrm{O}$ reductase play important roles in these two steps of denitrifying metabolism
$[24,25]$. Recently, Zhou et al. demonstrated that the $\mathrm{N}_{2} \mathrm{O}$ reduction rate seemed to be independent of $\mathrm{pH}$, whereas the inhibitory effect was much more moderate in comparison to that of FNA, when using denitrifying enhanced biological phosphorus removal sludge [8].

In batch experiment 1 , at a similar nitrite concentration in the initial anoxic phase, the $\mathrm{N}_{2} \mathrm{O}$ reduction rate was different before and after the exhaustion of nitrite (Figure 4). After nitrite was exhausted, the $\mathrm{N}_{2} \mathrm{O}$ reduction rates were similar $(6.65,6.33$, and $6.33 \mathrm{mgN} /(\mathrm{h} \cdot \mathrm{gVSS})$ ) despite different $\mathrm{pH}$ conditions when the $\mathrm{N}_{2} \mathrm{O}$ was not detected in the reactor at $107 \mathrm{~min}, 90 \mathrm{~min}$, and $80 \mathrm{~min}$, respectively. However, before the exhaustion of nitrite, the rise in FNA concentrations resulted in the decrease of $\mathrm{N}_{2} \mathrm{O}$ reduction rates $(1.72,3.15$, and $6.52 \mathrm{mgN} /(\mathrm{L} \cdot \mathrm{g} \mathrm{VSS})$ ), at the corresponding times of $113 \mathrm{~min}, 110 \mathrm{~min}$, and $100 \mathrm{~min}$. This may indicate that the $\mathrm{N}_{2} \mathrm{O}$ reduction rate was mainly affected by FNA in the denitrifying phosphorus removal process. In contrast, as shown in Table 2 and Figure 2(a), FNA also inhibited the $\mathrm{NO}_{2}{ }^{-}$to $\mathrm{N}_{2} \mathrm{O}$ step (nitrite reduction rate), which resulted in the highest $\mathrm{N}_{2} \mathrm{O}$ accumulation occurring at $0.0031 \mathrm{mg}$ $\mathrm{HNO}_{2}-\mathrm{N} / \mathrm{L}$ (corresponding to $\mathrm{pH}$ 7.5). The proportion of highest $\mathrm{N}_{2} \mathrm{O}$ accumulation to TN was from 18.8 to $78.42 \%$. 


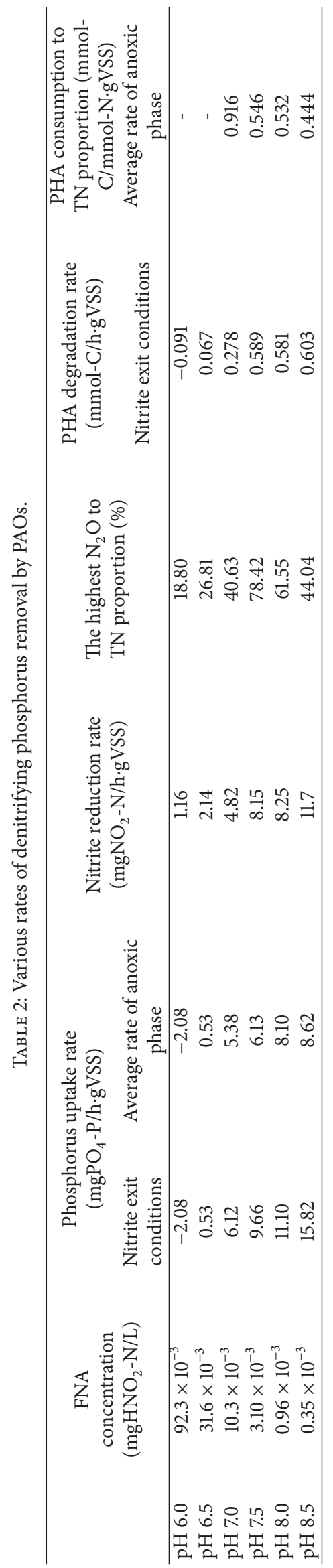




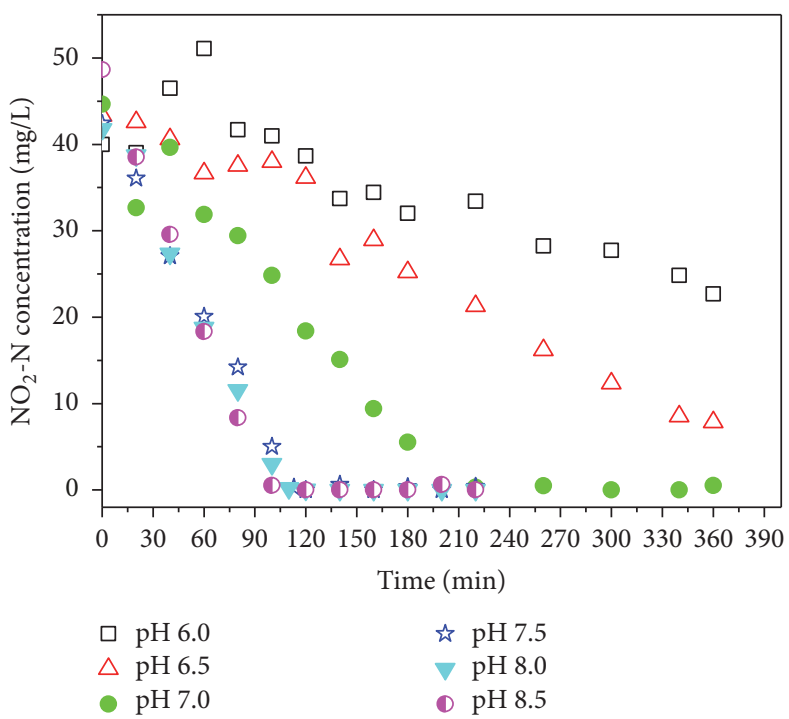

(a)

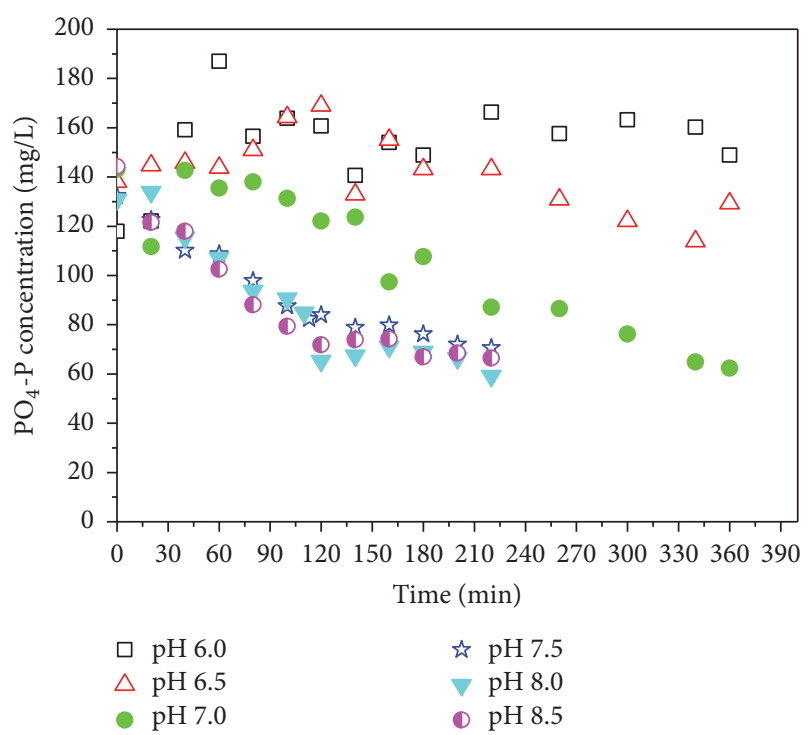

(b)

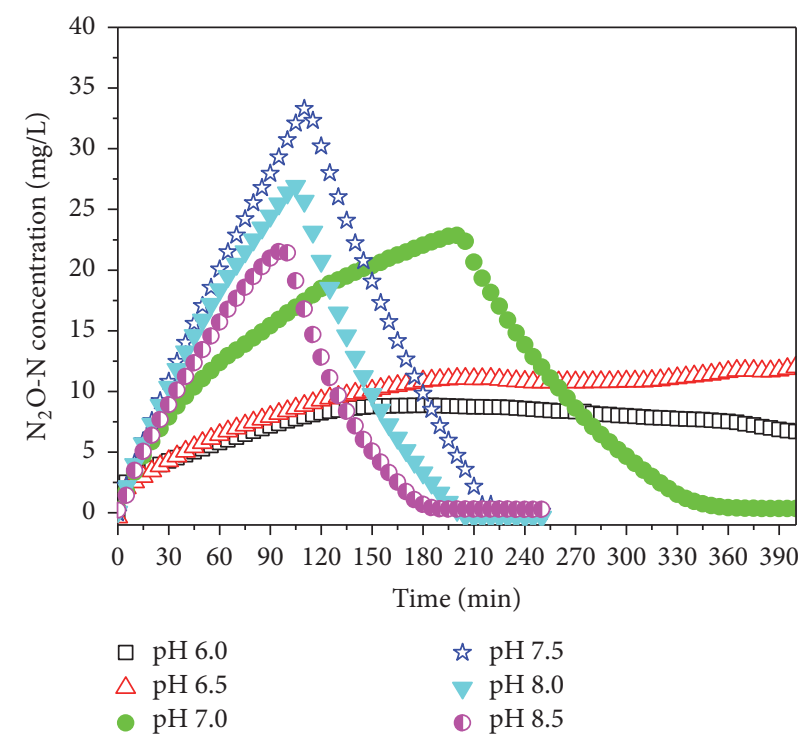

(c)

FIGURE 2: Profiles of nitrite, phosphorus, and nitrous oxide: (a) nitrite reduction; (b) phosphorus uptake; (c) $\mathrm{N}_{2} \mathrm{O}$ production. ( $\mathrm{pH}$ of 6.0, 6.5, $7.0,7.5,8.0$, and 8.5 corresponds to $0.0923,0.0316,0.0103,0.0031,0.00096$, and $0.00035 \mathrm{mgHNO}_{2}-\mathrm{N} / \mathrm{L}$, resp.).

3.2.4. Comparison of PHA Consumption Performance in Batch Experiment 1. The type of carbon source is important in influencing $\mathrm{N}_{2} \mathrm{O}$ production under anoxic conditions. In the current study, PHA played a key role in $\mathrm{N}_{2} \mathrm{O}$ production during denitrifying phosphorus removal [9]. In this study, the carbon source for denitrification was PHB and PHV. The surplus levels of PHB and PHV at the end of the anoxic phase were above $58 \%$. This suggests that a shortage of carbon source was not a main inhibitory factor for the metabolic process. The PHA degradation rates for concentrations of $0.0316,0.0103,0.0031,0.00096$, and $0.00035 \mathrm{mgHNO}_{2}-\mathrm{N} / \mathrm{L}$ were $0.067,0.278,0.589,0.581$, and $0.603 \mathrm{mmol}-\mathrm{C} /(\mathrm{h} \cdot \mathrm{g}$ VSS), respectively, before exhaustion of nitrite in the reactor (Table 2). However, PHA was synthesized instead of being degraded at $0.0923 \mathrm{mgHNO}_{2}-\mathrm{N} / \mathrm{L}$. The PHA degradation rate sharply decreased from $0.0106 \mathrm{mgHNO}_{2}-\mathrm{N} / \mathrm{L}$ to $0.0316 \mathrm{mgHNO}_{2}-\mathrm{N} / \mathrm{L}$. Some studies suggest that FNA has a stronger inhibitory effect on energy-consuming, rather than energy-generating, processes by DPAOs [26, 27]. In this study, the process related to energy generation, namely, PHA degradation, was seriously inhibited at high FNA levels and completely collapsed at $0.0923 \mathrm{mgHNO}_{2}-\mathrm{N} / \mathrm{L}$.

The quantity of PHA consumption per nitrite in the denitrifying phosphorus removal process by PAOs is shown in Table 2. Only the data that operated within the range of 0.00035 to $0.0103 \mathrm{mgHNO}_{2}-\mathrm{N} / \mathrm{L}$ are listed, due to the complete consumption of $\mathrm{TN}$ during the processes above. The levels of PHA/TN per biomass were 0.444, 0.532, 0.546, and $0.916 \mathrm{mmol}-\mathrm{C} /(\mathrm{mmol}-\mathrm{N} \cdot \mathrm{gVSS})$, respectively. Therefore, we could infer that a higher FNA concentration would lead 


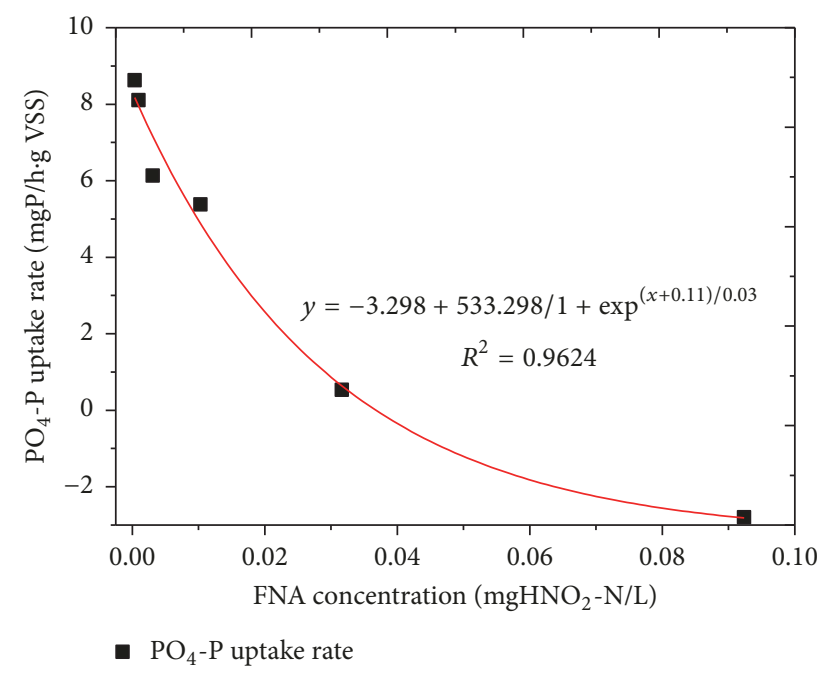

FIGURE 3: The inhibitory effect of FNA on PAO activity and P uptake rates.

to more PHA consumption during the initial anoxic phase. A possible explanation is that FNA could passively diffuse across the cell membrane and shuttle protons between the two sides without generating energy, which may induce the collapse of the proton motive force (PMF); therefore, the cell should pump out more protons in order to resist this trend $[8,28]$. In other words, more PHA was consumed to provide energy and protons to maintain the PMF balance or to recover from the inhibition that resulted from the absence of nitrite, when anoxic phosphorus removal occurred at the higher initial FNA concentration.

3.3. Batch Experiment 2. In batch experiment 1, the increase in FNA concentrations resulted in a decrease of the nitrite reduction rate, phosphorous uptake and $\mathrm{N}_{2} \mathrm{O}$ reduction. $\mathrm{N}_{2} \mathrm{O}$ accumulated due to the inhibition of the $\mathrm{N}_{2} \mathrm{O}$ reduction rate. However, further evidence was needed to demonstrate whether FNA was more crucial than $\mathrm{pH}$. In batch experiment 2 , various quantities of nitrite were added to the PAO sludge at two $\mathrm{pH}$ levels to test effects of FNA on $\mathrm{N}_{2} \mathrm{O}$ reduction rates and phosphorus uptake rates (Table 1).

At $\mathrm{pH} 7.5$, the $\mathrm{N}_{2} \mathrm{O}$ reduction rates were $3.465,2.695$, and $1.92 \mathrm{mgN} /(\mathrm{h} \cdot \mathrm{gVSS})$, while the $\mathrm{PO}_{4}-\mathrm{P}$ uptake rates were 12.24, 6.80, and $5.34 \mathrm{mgP} /(\mathrm{h} \cdot \mathrm{gVSS}$ ) (Figures 5(a) and 5(b)). Both rates decreased under the same $\mathrm{pH}$ conditions. The average value of the maximum $\mathrm{N}_{2} \mathrm{O}$ reduction rates and $\mathrm{PO}_{4}-\mathrm{P}$ uptake rates decreased by $44.6 \%$ and $56.4 \%$, respectively, at which time the FNA concentration increased from 0.01781 to $0.02814 \mathrm{mgHNO}_{2}-\mathrm{N} / \mathrm{L}$. Meanwhile, similar trends were observed for $\mathrm{pH}$ 7.0. The results provide evidence that higher initial FNA concentrations, not $\mathrm{pH}$, cause a lower $\mathrm{N}_{2} \mathrm{O}$ reduction rate and phosphorus uptake rate in denitrifying phosphorus removal by PAOs. Therefore, FNA has an important effect on anoxic phosphorus removal and on $\mathrm{N}_{2} \mathrm{O}$ production. This finding is consistent with results from Wang et al., who reported that nitrite addition to DPAO sludge stimulated the net $\mathrm{N}_{2} \mathrm{O}$ production rate due to FNA inhibition [9]. Zhou et al. reported a 50\% inhibition

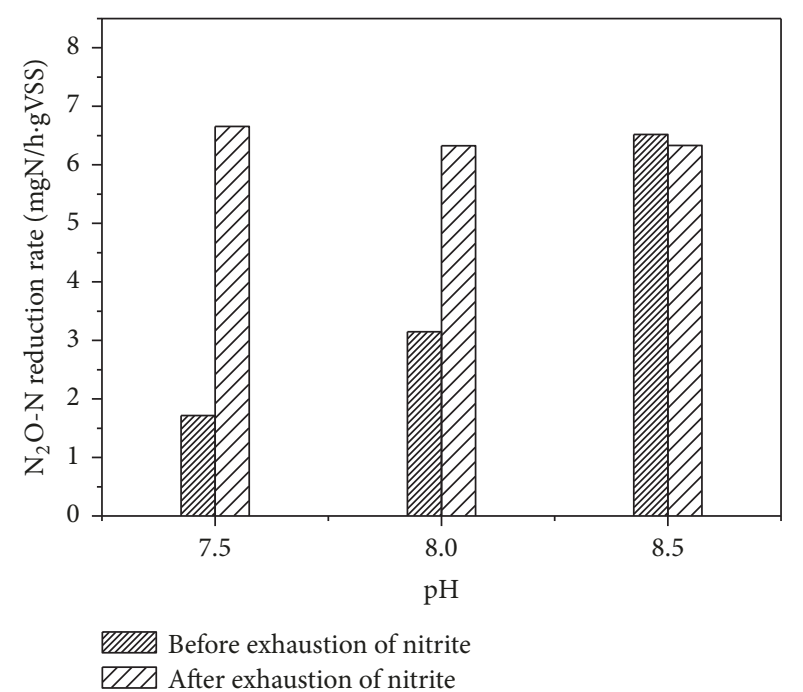

FIGURE 4: Various $\mathrm{N}_{2} \mathrm{O}$ reduction rates in the presence or absence of nitrite ( $\mathrm{pH}$ of 7.5, 8.0, and 8.5 corresponds to $0.0031,0.00096$, and $\left.0.00035 \mathrm{mgHNO}_{2}-\mathrm{N} / \mathrm{L}\right)$.

at FNA concentrations between 0.0007 and $0.001 \mathrm{mgHNO}_{2}-$ $\mathrm{N} / \mathrm{L}$, while the procedure was carried out to an FNA concentration of $0.004 \mathrm{mgHNO}_{2}-\mathrm{N} / \mathrm{L}$ [8]. In our study, FNA concentrations ranged from 0.00587 to $0.02815 \mathrm{mgHNO}_{2}$ $\mathrm{N} / \mathrm{L}$ (Table 1), and the total inhibitory concentration was $0.02815 \mathrm{mgHNO}_{2}-\mathrm{N} / \mathrm{L}$, providing strong evidence that FNA has a main inhibitory effect on the $\mathrm{N}_{2} \mathrm{O}$ reduction rate, resulting in accumulation of $\mathrm{N}_{2} \mathrm{O}$.

3.4. The Performance of ORP in Batch Experiment 1. Many studies have reported that Oxidation-Reduction Potential (ORP) is the main parameter for determining the nitrate or nitrite depletion point during anoxic nitrogen removal $[29,30]$. The nitrate or nitrite knees were a flex with a negative slope in the ORP curve and were more clearly shown in the sharply decreasing value of $d_{\mathrm{ORP}} / d_{t}$. The ORP curve at $\mathrm{pH} 8.0$ during denitrifying phosphorus removal is shown in Figure 6; similar results were observed at $\mathrm{pH} 7.0,7.5$, and 8.5. The nitrite knee appeared at $99 \mathrm{~min}$ while the concentration of nitrite was $3 \mathrm{mg} / \mathrm{L}$ (Figure 6). It is feasible to consider that this value was a nitrite knee point according to the traditional explanation; however, TN still existed in the form of $\mathrm{N}_{2} \mathrm{O}$ at a concentration of $26.05 \mathrm{mg} / \mathrm{L}$. Hence, using this nitrite knee to indicate the end of the denitrifying phosphorus removal process is not appropriate, and part of dissolved $\mathrm{N}_{2} \mathrm{O}$ could be diffused into the air if the denitrifying phosphorus removal immediately stopped at this time. Meanwhile, it is also difficult to use an $\mathrm{N}_{2} \mathrm{O}$ probe to indicate the end of denitrifying phosphorus removal due to its fragility. Further studies should focus on other efficiency parameters that can be used in denitrifying phosphorus removal.

\section{Conclusions}

The FNA concentration significantly influenced the denitrifying phosphorus removal process by PAOs when nitrite 


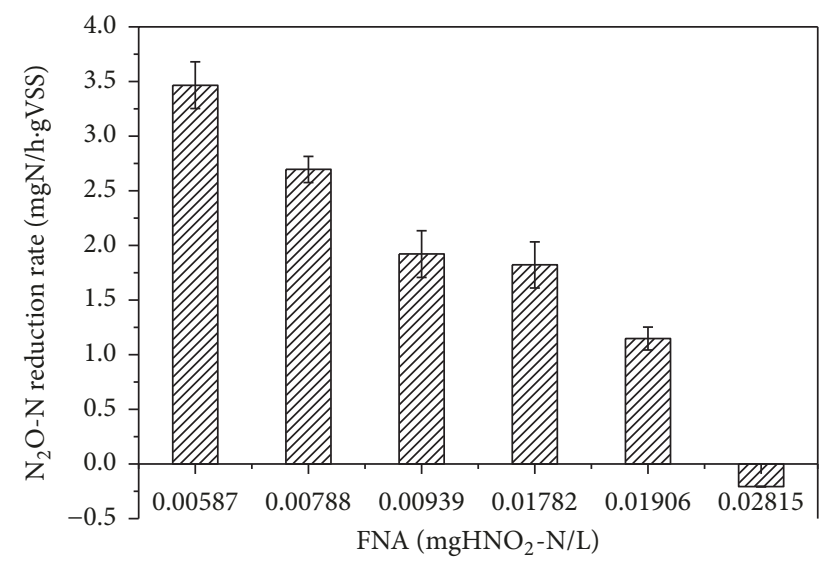

VIIIA $\mathrm{N}_{2} \mathrm{O}-\mathrm{N}$ reduction rate

(a)

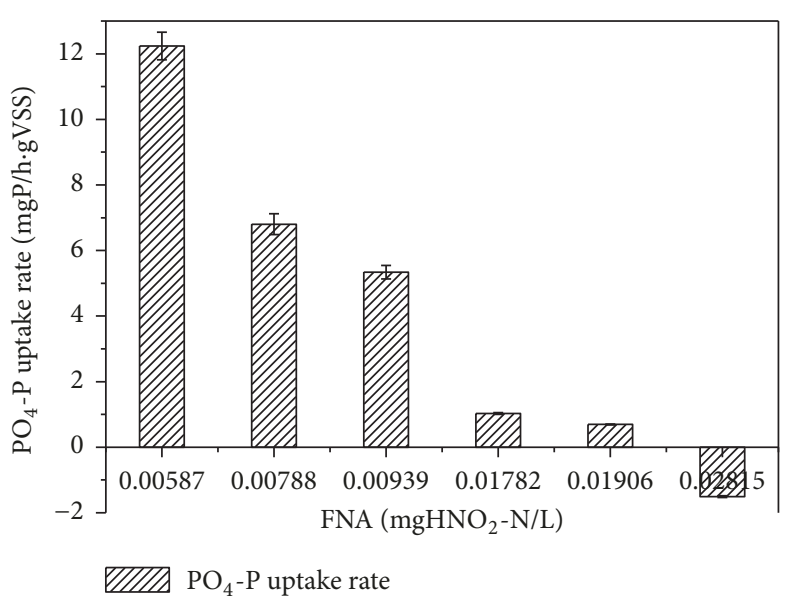

(b)

FiguRE 5: Effects of FNA on $\mathrm{N}_{2} \mathrm{O}$ reduction rates and phosphorus uptake rates in batch experiment 2: (a) $\mathrm{N}_{2} \mathrm{O}$ reduction rate; (b) phosphorus uptake rate.

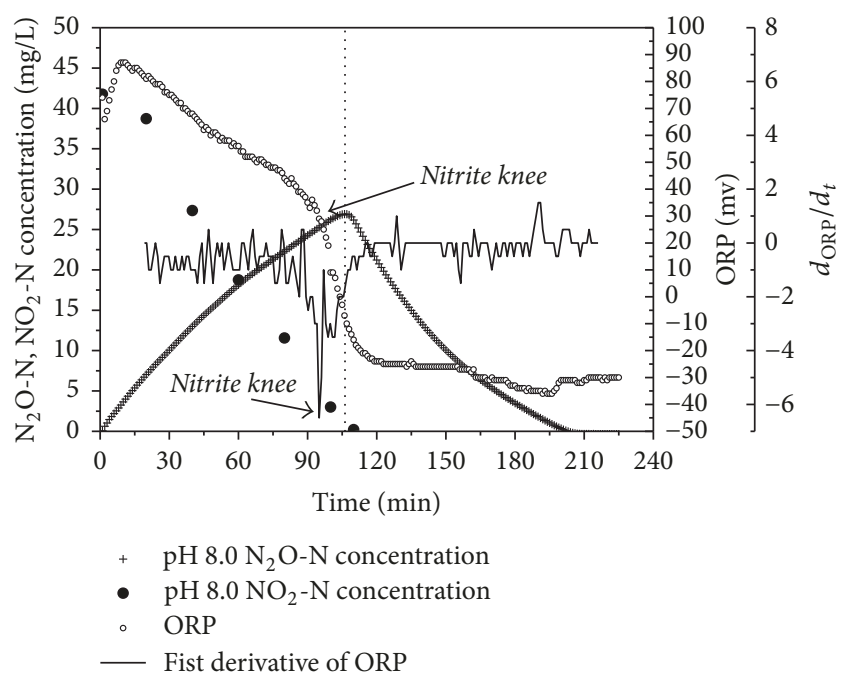

FIGURE 6: Various ORP in denitrifying phosphorus removal.

was added as the electron acceptor. The nitrite reduction rate, phosphorus uptake rate, $\mathrm{N}_{2} \mathrm{O}$ reduction rate, and PHA degradation rate also decreased as the concentration of FNA increased. FNA prevented the step from $\mathrm{NO}_{2}$ and $\mathrm{N}_{2} \mathrm{O}$ to $\mathrm{N}_{2} \mathrm{O}$ and $\mathrm{N}_{2}$. In addition, when the FNA concentration was approximately $0.0031 \mathrm{mgHNO}_{2}-\mathrm{N} / \mathrm{L}$ (equivalent to $42.44 \mathrm{mgNO}_{2}-\mathrm{N} / \mathrm{L}$ at $\mathrm{pH} 7.5$ ), the accumulation of $\mathrm{N}_{2} \mathrm{O}$ approaches $33.28 \mathrm{mgN}_{2} \mathrm{O}-\mathrm{N} / \mathrm{L}$ during the anoxic denitrification process, accounting for $78.42 \%$ of the total nitrogen. The traditional nitrite knee point can only indicate the exhaustion of nitrite, instead of the complete removal of TN.

\section{Conflicts of Interest}

The authors declare that they have no conflicts of interest.

\section{Acknowledgments}

This research was financially supported by Natural Science Fund of Hebei Province (E2016403035); Colleges and Universities in Hebei Province Science and Technology Research Projects (QN2014037, ZD2016154); Science and Technology Project of Hebei Province (15274015D).

\section{References}

[1] J. Ahn, T. Daidou, S. Tsuneda, and A. Hirata, "Metabolic behavior of denitrifying phosphate-accumulating organisms under nitrate and nitrite electron acceptor conditions," Journal of Bioscience and Bioengineering, vol. 92, no. 5, pp. 442-446, 2001.

[2] S. Ge and P. Champagne, "Nutrient removal, microalgal biomass growth, harvesting and lipid yield in response to centrate wastewater loadings," Water Research, vol. 88, pp. 604-612, 2016.

[3] J. Meinhold, E. Arnold, and S. Isaacs, "Effect of nitrite on anoxic phosphate uptake in biological phosphorus removal activated sludge," Water Research, vol. 33, no. 8, pp. 1871-1883, 1999.

[4] M. J. Kampschreur, H. Temmink, R. Kleerebezem, M. S. M. Jetten, and M. C. M. van Loosdrecht, "Nitrous oxide emission during wastewater treatment," Water Research, vol. 43, no. 17, pp. 4093-4103, 2009.

[5] N. Yoshida, "15N-depleted N2O as a product of nitrification," Nature, vol. 335, no. 6190, pp. 528-529, 1988.

[6] S. Ge, Y. Peng, S. Wang, C. Lu, X. Cao, and Y. Zhu, "Nitrite accumulation under constant temperature in anoxic denitrification process: The effects of carbon sources and $\mathrm{COD} / \mathrm{NO}_{3}-\mathrm{N}$," Bioresource Technology, vol. 114, pp. 137-143, 2012.

[7] Z. Wang, Y. Meng, T. Fan, Y. Du, J. Tang, and S. Fan, "Phosphorus removal and $\mathrm{N} 2 \mathrm{O}$ production in anaerobic/anoxic denitrifying phosphorus removal process: Long-term impact of influent phosphorus concentration," Bioresource Technology, vol. 179, pp. 585-594, 2015. 
[8] Y. Zhou, M. Pijuan, R. J. Zeng, and Z. Yuan, "Free nitrous acid inhibition on nitrous oxide reduction by a denitrifyingenhanced biological phosphorus removal sludge," Environmental Science \& Technology, vol. 42, no. 22, pp. 8260-8265, 2008.

[9] Y. Wang, J. Geng, Z. Ren et al., "Effect of anaerobic reaction time on denitrifying phosphorus removal and $\mathrm{N}_{2} \mathrm{O}$ production," Bioresource Technology, vol. 102, no. 10, pp. 5674-5684, 2011.

[10] Y. Zhou, M. Pijuan, and Z. Yuan, "Free nitrous acid inhibition on anoxic phosphorus uptake and denitrification by poly-phosphate accumulating organisms," Biotechnology and Bioengineering, vol. 98, no. 4, pp. 903-912, 2007.

[11] M. Pijuan, L. Ye, and Z. Yuan, "Free nitrous acid inhibition on the aerobic metabolism of poly-phosphate accumulating organisms," Water Research, vol. 44, no. 20, pp. 6063-6072, 2010.

[12] A. Guisasola, M. Qurie, M. D. M. Vargas, C. Casas, and J. A. Baeza, "Failure of an enriched nitrite-DPAO population to use nitrate as an electron acceptor," Process Biochemistry, vol. 44, no. 7, pp. 689-695, 2009.

[13] M. Vargas, A. Guisasola, A. Artigues, C. Casas, and J. A. Baeza, "Comparison of a nitrite-based anaerobic-anoxic EBPR system with propionate or acetate as electron donors," Process Biochemistry, vol. 46, no. 3, pp. 714-720, 2011.

[14] G. R. Crocetti, P. Hugenholtz, P. L. Bond et al., "Identification of polyphosphate-accumulating organisms and design of $16 \mathrm{~S}$ rRNA-directed probes for their detection and quantitation," Applied and Environmental Microbiology, vol. 66, no. 3, pp. 1175$1182,2000$.

[15] R. P. X. Hesselmann, C. Werlen, D. Hahn, J. R. Van Der Meer, and A. J. B. Zehnder, "Enrichment, phylogenetic analysis and detection of a bacterium that performs enhanced biological phosphate removal in activated sludge," Systematic and Applied Microbiology, vol. 22, no. 3, pp. 454-465, 1999.

[16] Y. Chen, A. A. Randall, and T. McCue, "The efficiency of enhanced biological phosphorus removal from real wastewater affected by different ratios of acetic to propionic acid," Water Research, vol. 38, no. 1, pp. 27-36, 2004.

[17] M.-T. Wong, T. Mino, R. J. Seviour, M. Onuki, and W.-T. Liu, "In situ identification and characterization of the microbial community structure of full-scale enhanced biological phosphorous removal plants in Japan," Water Research, vol. 39, no. 13, pp. 2901-2914, 2005.

[18] Z. Miao, W. Zeng, S. Wang et al., "Effect of temperature on anoxic metabolism of nitrites to nitrous oxide by polyphosphate accumulating organisms," Journal of Environmental Sciences, vol. 26, no. 2, pp. 264-273, 2014.

[19] A. C. Anthonisen, R. C. Loehr, T. B. S. Prakasam, and E. G. Srinath, "Inhibition of nitrification by ammonia and nitrous acid," Journal of the Water Pollution Control Federation, vol. 48, no. 5, pp. 835-852, 1976.

[20] C. M. Lopez-Vazquez, Y.-I. Song, C. M. Hooijmans et al., "Shortterm temperature effects on the anaerobic metabolism of glycogen accumulating organisms," Biotechnology and Bioengineering, vol. 97, no. 3, pp. 483-495, 2007.

[21] H. Daims, A. Brühl, R. Amann, K.-H. Schleifer, and M. Wagner, "The domain-specific probe EUB338 is insufficient for the detection of all bacteria: development and evaluation of a more comprehensive probe set," Systematic and Applied Microbiology, vol. 22, no. 3, pp. 434-444, 1999.

[22] G. Crocetti R., J. Banfield F., J. Keller, P. L. Bond, and L. L. Blackall, "Glycogen-accumulating organisms in laboratory-scale and full-scale wastewater treatment processes," Microbiology, vol. 148, no. 11, pp. 3353-3364, 2002.
[23] T. Kuba, G. Smolders, M. C. M. van Loosdrecht, and J. J. Heijnen, "Biological phosphorus removal from wastewater by anaerobic-anoxic sequencing batch reactor," Water Science and Technology, vol. 27, no. 5-6, pp. 241-252, 1993.

[24] T. Rasmussen, B. C. Berks, J. Sanders-Loehr, D. M. Dooley, W. G. Zumft, and A. J. Thomson, "The catalytic center in nitrous oxide reductase, $\mathrm{Cu}-\mathrm{Z}$, is a copper-sulfide cluster," Biochemistry, vol. 39, no. 42, pp. 12753-12756, 2000.

[25] M. Poth and D. D. Focht, "15N kinetic analysis of N2O production by Nitrosomonas europaea: An examination of nitrifier denitrification," Applied and Environmental Microbiology, vol. 49, no. 5, pp. 1134-1141, 1985.

[26] Y. Zhou, L. Ganda, M. Lim, Z. Yuan, S. Kjelleberg, and W. J. Ng, "Free nitrous acid (FNA) inhibition on denitrifying poly-phosphate accumulating organisms (DPAOs)," Applied Microbiology and Biotechnology, vol. 88, no. 1, pp. 359-369, 2010.

[27] V. M. Vadivelu, J. Keller, and Z. Yuan, "Effect of free ammonia and free nitrous acid concentration on the anabolic and catabolic processes of an enriched Nitrosomonas culture," Biotechnology and Bioengineering, vol. 95, no. 5, pp. 830-839, 2006.

[28] J. S. Almeida, S. M. Júlio, M. A. M. Reis, and M. J. T. Carrondo, "Nitrite inhibition of denitrification by Pseudomonas fluorescens," Biotechnology and Bioengineering, vol. 46, no. 3, pp. 194-201, 1995.

[29] D. G. Wareham, K. J. Hall, and D. S. Mavinic, "Real-time control of aerobic-anoxic sludge digestion using ORP," Journal of Environmental Engineering (United States), vol. 119, no. 1, pp. 120-136, 1993.

[30] Y. Z. Peng, J. F. Gao, S. Y. Wang, and M. H. Sui, "Use pH and ORP as fuzzy control parameters of denitrification in SBR process," Water Science and Technology, vol. 46, no. 4-5, pp. 131-137, 2002. 


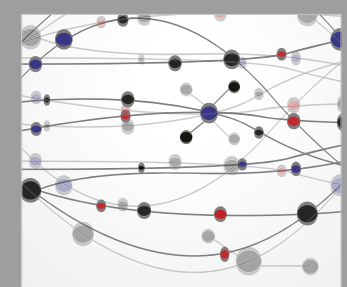

The Scientific World Journal
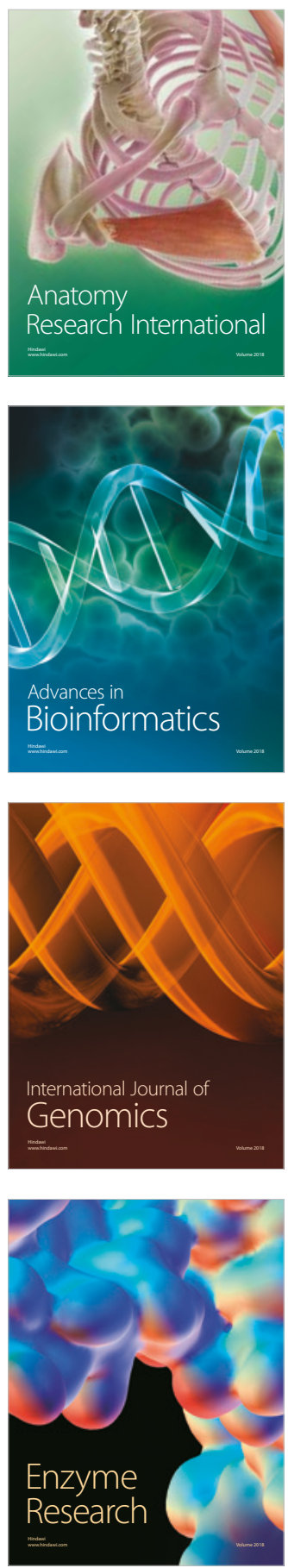
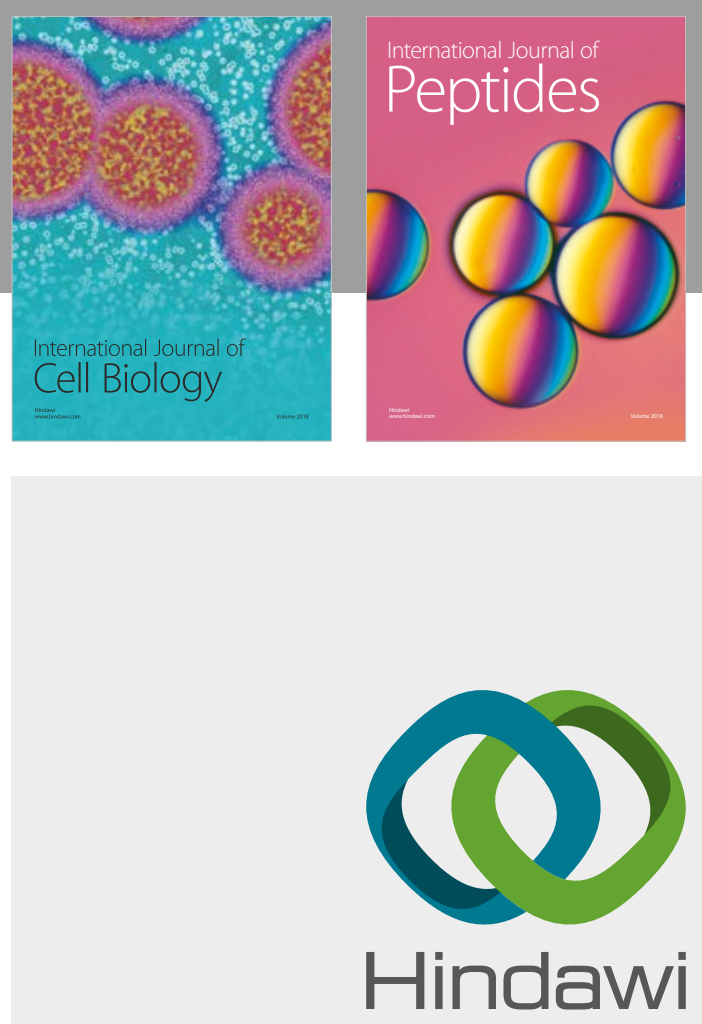

Submit your manuscripts at

www.hindawi.com
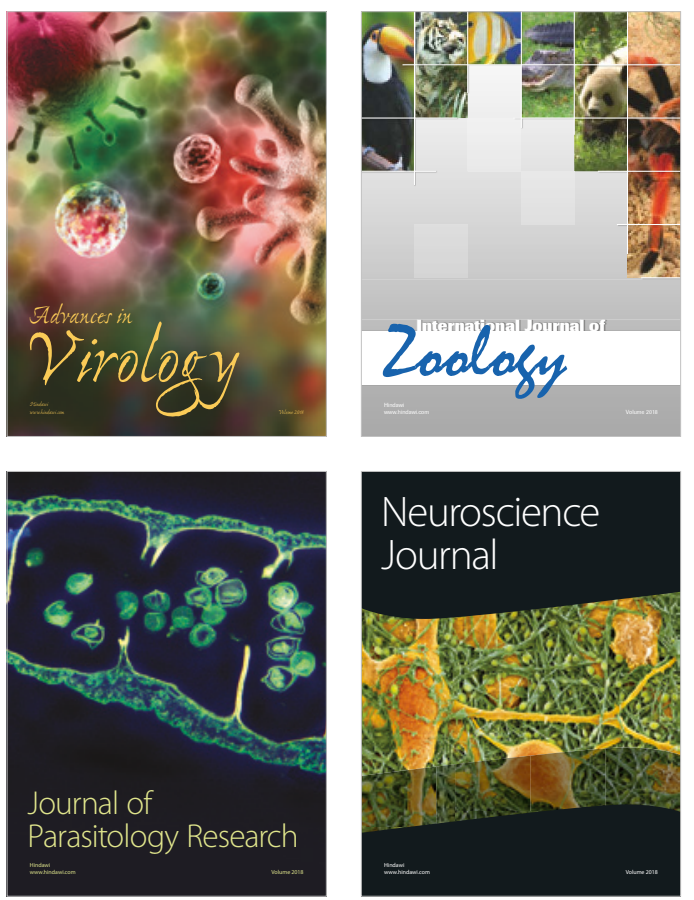
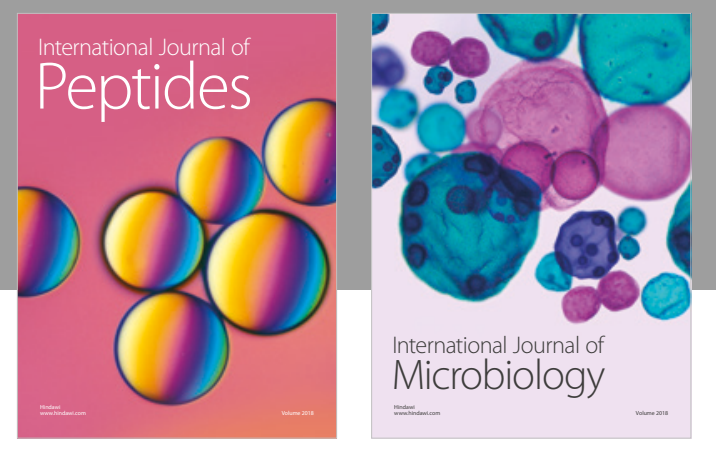

nternational Journal of Microbiology
Journal of
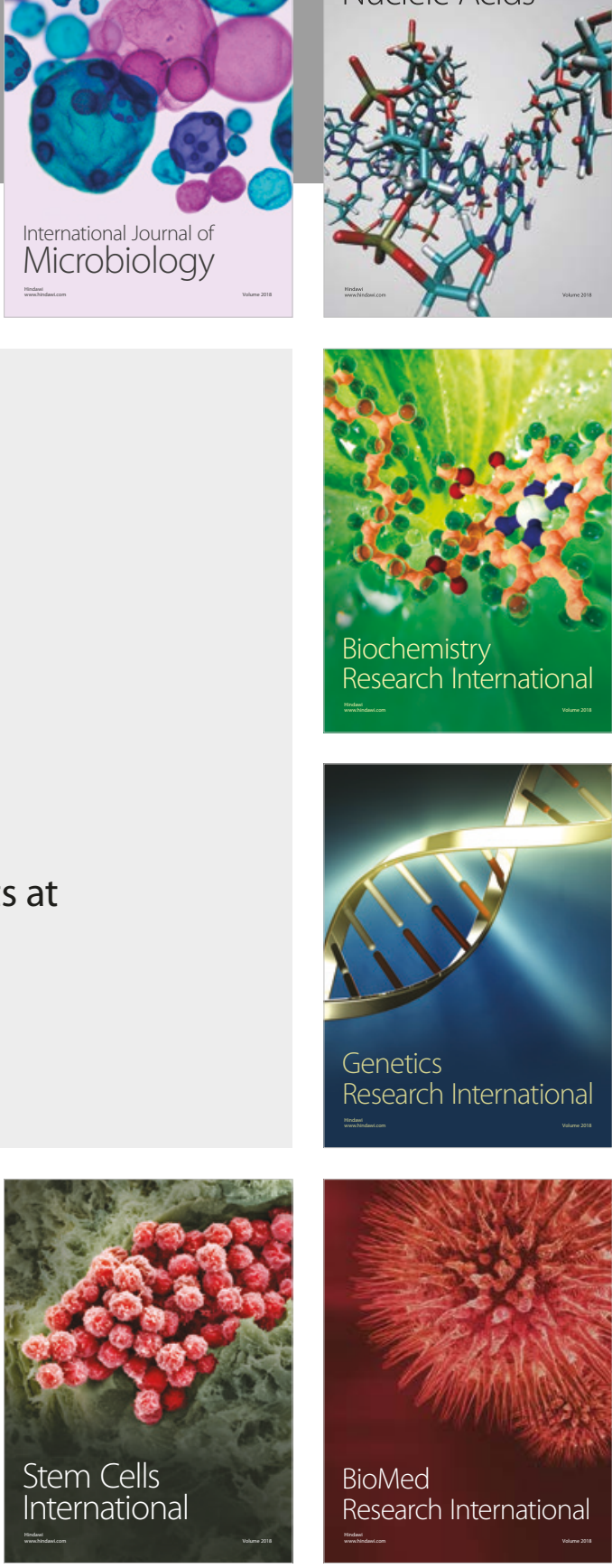
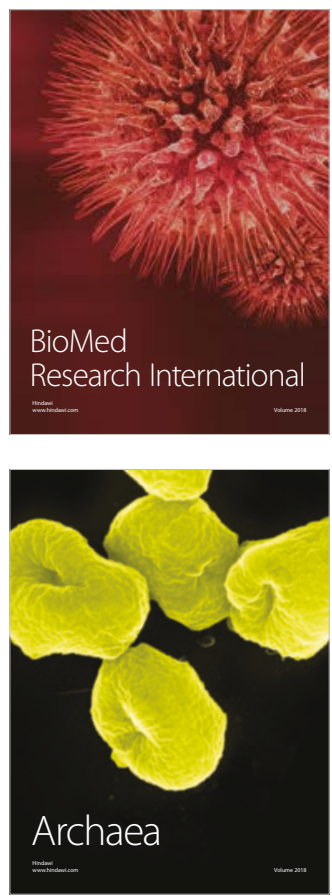